\section{APSA Members and Friends Continue to Provide Program Support}

Many of the Association's programs and awards would not continue to operate without the generosity of APSA members and friends of political science. APSA is very grateful to those who contribute to awards and other programs. During the past year these individuals have made a significant contribution to the Congressional Fellowship Program and the Trust and Development Fund.

Lupita Aguirre

Edward Artinian

Walter Beach

J. Cudd Brown

Allan Brown

Winber Chai

Pamela Conover

Eugene Davidson

Chris Deering

Daniel Estrada

Beth Fuchs

Henry Galant

Robert Gilpin

Nancy Green

Glen Halva-Neubauer

John Harrod

Jerzy Hauptman

Mark Herbst

Paul S. Herrnson

John F. Hoadley

Samuel Hoff

Joyce Kallgren

Thomas Kazee

Anthony King

Paul F. Kromer

Dianne Lambert

Lawrence LeDuc

Thomas R. Lewis

Leopoldo Lovelace

Ardith Maney

Mary Maxwell

Susan McAndrew

Douglas F. Morgan

Ward Morton

Burton Moyer

Yoshio Murakami

Frederick Neikirk

Robert Neiman

Dalmas Nelson

William Oakley

Kelly Patterson

W. Scott Payne

Frank Prindle

Ronald Reinighaus

Craig Rimmerman

Fauneil J. Rinn

Francis Rourke

Mark Schneider

Steven Scroggs
Harold Seidman

Roberta Sigel

Robert Simmons

Albert Somit

William Spragens

Ichiro Sunada

Edward Thompson

Charles Tidmarch

Sue Vandenbosch

Shuishi Wada

Steve Wasby

Patricia Woods

\section{Section News:}

\section{New Section on Elections and Electoral Behavior}

Elections and Electoral Behavior is a new organized section approved by the APSA Council in the spring of 1993. The purpose of this section is to promote interest in teaching and research in the areas of elections, electoral behavior, voting turnout, and political participation, both within the United States and in comparative perspective. It is intended to be a broad-gauged section devoted to the study of elections.

Individuals interested in participating in the section are invited to attend the section organizational meeting at the 1993 American Political Science Association meetings. Please consult the program for time and location.

The organizers of the section are Herb Weisberg at the Ohio State University, Kathleen Knight at the University of Houston, and George Rabinowitz at the University of North Carolina. Contact any of them with questions or suggestions regarding the section.

\section{APSA Research Support Grants Announced}

The APSA Research Support Committee recently announced 11 awards totaling $\$ 15,000$ under APSA's program to support research by political scientists outside of Ph.D.-granting, research institutions. These awards are supported entirely by Association general revenuesthat is, by member dues-as one of the many facets of the Association's commitment to assuring scholarly opportunities for all. The Committee received 41 proposals.

The awards were approved by the APSA Council at its April 17th meeting. They are merit-based and this year include studies of a comparison across constitutional issues, political recruitment in France, rural political economy, abortion policy, a case study of the Polish parliament, mass opinion on AIDS, structure of candidate trait information, women's PACs, Zambian agricultural policymaking, and women in politics in Ecuador. The Research Support Committee is chaired by John Sprague, Washington University, and includes F. Chris Garcia, University of New Mexico; Kathleen Knight, University of Houston; Stanley Rothman, Smith College; and Karen O'Connor, Emory University.

The grant recipients are Jilda $\mathbf{M}$. Aliotta, University of Hartford, "Assessing Judicial Attributes v. Case Characteristics: A Comparison Across Constitutional Issues"; Andrew Appleton, Canisius College, "Party Organizations and Political Recruitment in France: The French Candidate Survey"; Allison Drew, University of Nevada, Las Vegas, "Rural Political Economy and the Political Culture of Land in South Africa"; Glen A. Halva-Neubauer, Furman University, "Legislative Agenda Setting in the States: The Case of Abortion Policy"; Janine P. Holc, Loyola College, "InstitutionBuilding in Post-Communist Politics: A Case Study of the Polish Parliament"; Nuket Kardam, Pomona College, "Central Asia and Turkey: The Politics of an Emerging Economic Bloc"; Philip H. Pollock, III, University of Central Florida, "Testing a Model of Critical Moments: Magic Johnson and Mass Opinion on AIDS"; David R. Reed, Arkansas State University, "The Media and the Structure of Candidate Trait Contributors"; Susan L. Roberts, Furman University, "Women's PACs: A Study of Organizations and Their Contributors"; Eve N. Sandberg, Oberlin College, "Donor Influence in an African State: The Case of Zambian Agricultural Policy Making"; Richard L. Wilson, Sam Houston State University, "Women in Politics in Ecuador." 